\title{
Can Self-Build Housing improve Social Sustainability within Low-Income Groups?
}

\section{Helena Obremski}

Senior Planning Officer

Email: helena_ruth@hotmail.co.uk

Claudia E. Carter (corresponding author)

Reader in Environmental Governance / Associate Professor

School of Engineering and Built Environment

Birmingham City University

Millennium Point, Curzon Street, Birmingham B4 7XG, England, United Kingdom

E-mail: claudia.carter@bcu.ac.uk

orcid.org/0000-0003-4144-0259

Article accepted for publication in the Town Planning Review (TPR)

Submitted: 23 July 2018

Accepted: 25 November 2018

\section{Plain Language Summary}

Past research has shown conflicting viewpoints regarding the positive and negative influences that a collective approach to housing has on participation, social cohesion and social capital. Our research of five affordable communal self-build housing development projects in England and Wales showed that a formal social structure and continued shared visioning within self-build housing communities are crucial in maintaining social cohesion and participation.

\section{Acknowledgments}

We would like to thank all of the interviewees who gave up their time to take part in the research project. Figure 1 was kindly redrawn by Micahla de Cann and Figure 2 by Andrea Obremski to look much neater. We would also like to thank Silvia Gullino who offered very useful feedback on an advanced draft and the three anonymous reviewers for their helpful pointers to further improve the paper. 


\title{
Can Self-Build Housing improve Social Sustainability within Low-Income Groups?
}

\begin{abstract}
This paper explores how affordable communal self-build housing affects levels of social cohesion, social capital and participation amongst low-income community members. Thematic analysis of in-depth interviews with members of five low-cost self-build communities in England and Wales elicited that through a shared vision and sustained common sense of purpose, high levels of social capital and participation were evident at the start of the projects, and can continue into later phases. However, without a formal social structure and continued shared visioning within self-build housing communities, social cohesion was found to deteriorate with negative consequences for participation, and in some cases showing a lack of social cohesion or leading to conflict.
\end{abstract}

Keywords: social sustainability, social cohesion, social capital, participation, affordable housing, self-build housing, low-income groups.

\section{Introduction}

A lack of affordable housing ${ }^{1}$ is a significant international concern leaving economicallydeprived individuals and communities at a significant disadvantage when seeking accommodation and presenting a major policy issue in many developing and developed nations (e.g. Sullivan and Ward, 2011; Soliman, 2012; Blanco and Leon, 2017). Over the past decades, a turn towards decentralization has encouraged local Governments and communities to take responsibility for housing provision, juxtaposed with attempts to recover from the economic recession and associated spending cuts (Carter, 1997; Bramley, 2016; Garcia and Haddock, 2016).

The lack of low-cost housing and funding and the effects of decentralisation have led to increased rates of self-mobilisation of socially vulnerable groups (Blanco and Leon, 2017) and the development of self-help housing (Bredenoord and van Lindert, 2010). In developing countries, self-build tends to be poor quality informal housing and is often the only means of obtaining shelter for low-income communities (Landman and Napier, 2009; Sullivan and Ward,

\footnotetext{
${ }^{1}$ We use 'affordable housing' to mean housing which is adequate in standard and location and at a cost that does not prevent meeting other basic needs for those on low income or social support. In that sense our use of 'affordable' means housing at a low cost, irrespective of whether this is fulfilled through the market or social provisions and whether owned/mortgaged or rented.
} 
2011). Communities in developed nations have also turned to self-build housing; however, research indicates that government incentives to drive such schemes are focused on the middle classes (Bredenoord and van Lindert, 2010) although (informal) self-build by low/no income individuals or communities also exist. There have been attempts in America and Egypt to formalise informal settlements and provide more sustainable, low-cost housing solutions, but with limited success (Sullivan and Ward, 2011; Soliman, 2012).

In the UK, the National Self Building Association (NaSBA) propose that self-build housing could provide more affordable and shared equity homes (NaSBA, 2011). Market research conducted in 2013 suggests that the self-build market currently represents about $8 \%$ of new homes (Homebuilding and Renovating Market Research, 2013) with an undefined percentage of this being low-cost. Available government-derived figures (e.g. DCLG, 2011) indicate that the UK remains far behind the rest of the world in terms of delivery of self-build housing with around $10 \%$ self-build compared with $30-80 \%$ in several European countries, Australia, New Zealand, USA and Canada; even though definitions for self-build vary and the data for the UK is obtained by inference rather than directly measured. This paper adopted the definition by the UK Housing and Planning Act 2016 (DCLG, 2016, 6) which defines self-build housing as the "building or completion by- (a) individuals, (b) associations of individuals, or (c) persons working with or for individuals or associations of individuals, of houses to be occupied as homes by those individuals."

In the context of affordable housing, self-build homes may carry more benefits than just providing accommodation for low-income groups. Of interest here is assessing their role in increasing social sustainability, and especially creating or enhancing sustainable communities. Section 2 therefore reviews recent publications that shed light on the contribution of self-build in creating sustainable communities and relevant factors with particular attention to nonphysical social sustainability factors, namely social cohesion, social capital and community participation within the context of the physical social sustainability factor of 'decent housing' (see Dempsey et al., 2009, Table 1). Dempsey et al. (2009) identified a number of non-physical social factors which affect sustainability and concluded that sustainability of community, or the functioning of a society in the form of a community, is core to social sustainability, and identified some connections between participation, social capital and social cohesion. Our paper focuses on the current knowledge gap about low-income communities, assessing five self-build projects in England to further investigate and clarify key factors in creating sustainable communities through self-build affordable housing initiatives (sections 3-5). 


\section{Context and 'Theoretical Framework'}

In this paper 'community' means a small-scale network of residents, who may have collective interests and a shared experience of developing and/or living in a neighbourhood where the homes were constructed by the residents. We start by examining the literature relating to sustainable communities and how the construction and living in affordable self-build communities affects certain social factors, principally social cohesion, social capital and participation.

\subsection{Sustainable Communities}

Assessing the link between the built environment and social cohesion, there is evidence that high-quality environments help create social inclusion, social capital and provide more residential stability (Dempsey, 2009). Academic literature on self-built affordable housing have so far mainly focused on environmental sustainability and improving the quality of settlements (e.g. Gullino, 2008; Maline et al., 2008; Sefyang, 2010). Relatively few studies have considered social sustainability of low-income communities.

Solidarity often emerges as the response to a crisis (such as a lack of safe, convenient and affordable housing), also stimulating social innovation which creates social support structures (Blanco and Leon, 2017), and can strengthen social cohesion within the crisis affected community. Townshend et al. (2015) claim that socially cohesive societies are more resilient, owing to the ability to react to threats more easily, which can be identified through support networks, social capital and unity. Through active participation and co-ordinated efforts, a sense of belonging is fostered, which in turn helps develop community resilience (Townshend et al., 2015). Ha (2007, 2008) suggests that when considering social sustainability in connection with social housing, local issues need to be addressed by locally sourced responses from residents, building on and fostering social capital to achieve greater self-reliance. Social capital has been defined in a number of ways; however some general consensus exists that it denotes the social relationships between networks of groups, characterised by mutual trust which can improve the efficiency of a society, by encouraging working with one another (e.g. information sharing, coordination of activities, collective decision making) to achieve mutually desired outcomes (Lehtonen, 2004; Saegert and Winkel, 2004;).

There seems to be a virtuous cycle between participation, empowerment and social capital. Ahmad and Abu Talib (2016) propose that social resilience and capacity building are closely linked with empowerment and increased levels of participation in the context of community driven projects. Furthermore, Mahjabeen et al. (2009) explain that community participation leads to plans which better reflect stakeholder needs, therefore delivering social and economic 
benefits, and 'more sustainable' development. In relation to self-build housing, there is currently little explicit evidence on how participation evolves over time and how or why factors such as social capital and social cohesion form and change. Sullivan and Ward (2011) touch on social sustainability within self-build housing, suggesting that this is achieved through participation which is augmented by the process of building and sustainable living practices. However, once neighbourhoods are developed, public participation may in fact diminish, requiring aid and regeneration projects to revitalise these areas once more.

Self-build housing projects have led to increased levels of social interaction through the physical acts of sharing resources, skills and knowledge (Hammiduddin, 2015). How self-build affects levels of participation beyond the building phase and impacts on social capital, social cohesion and sense of community is, however, not expressly explored in the existing literature and therefore formed the explicit focus of our research.

Next, the specific themes of community participation and sense of community, social cohesion and social capital are further explored as these were prominent concepts in the literature and constitute our framework for assessing low-income self-build housing through its various stages.

\subsection{Community Participation and Sense of Community}

Community participation is about engagement of members within a group which affect the individuals' lives and the whole community; sense of community is described as key to achieving effective participation (Talo et al., 2014). Some research (e.g. Putnam, 2001; Talo et al., 2014) contends that community participation (defined here as active engagement processes) and sense of community (defined as feelings of trust and belonging) improve quality of life, increase empowerment and have a positive impact on social capital. McMillan and Chavis (1986) define indicators of sense of community as being: membership of a group, influence over decision making within a group context, fulfilment of needs and a shared emotional connection. Sense of community can positively impact on social cohesion (Wilkinson, 2007) and is therefore considered to represent a key identifier for assessing how effective participation is within a community. Talo et al.'s (2014) study concluded that when people are involved in civic forms of engagement, they displayed a high sense of community. Self-build housing is considered to represent a civic form of engagement in terms of the input which individuals and communities have throughout the duration of the project with each other and also with the local government.

\subsection{Social Cohesion}

Kearns and Forrest (2001) define a socially cohesive society as one which displays a sense of common purpose, has social order, a sense of community and social interaction. They also suggest that the neighbourhood is the most important platform for assessing shared identities. 
Social cohesion is created through a sense of belonging, inclusion, recognition, legitimacy and collaboration (Townshend et al., 2015). While Cheung and Leung (2011) suggest that homogeneous communities (people with similar backgrounds) foster social cohesion, Laurence (2011) contends that neighbourhood diversity does not affect social interaction. However, the importance of the impact of common interest on social cohesion and participation has been highlighted in several studies. For example, Kearns and Forrest (2001) purport that the act of coming together to promote or defend a common local interest can foster social cohesion. Forrest and Kearns (2001) also state that the implied characteristics of a community which suffers from low levels of social cohesion is one that has social disorder, conflict and low levels of participation. This in turn may imply that a socially cohesive society would be void of conflict, which is, however, a simplistic view.

\subsection{Social Capital}

Social capital is built through human interactions, relational changes and connections that lead to action; it can be defined as the aggregate capabilities pertaining to knowledge and skills of individuals (Coleman, 1988). Putman et al. (1993) identified social norms, network structures and trust to influence social capital. Putnam (2001) introduced the themes of "bonding social capital" (the networks and relationships within communities) and "bridging social capital" (the relationships between groups or organisations). Crawford et al.'s (2008) study identified that community participation assisted in creating social capital, with more bonding rather than bridging. Empirical research seems to be focusing largely on identifiers of social capital (Menzel et al., 2013) and the beneficial impacts of communities rich in social capital, whereas explorations of how social capital evolves over time seems to be lacking.

Social capital can facilitate group advantage, which is developed through shared experiences as identified by Coleman (1988); in relation to self-build communities through coming together to construct housing, often sharing skills and information to achieve group advantage (Benson, 2015). Moreover, Holman and Rydin (2013) suggest that the relationships built through social capital develop commitment and encourage people to participate in activities which they may not usually have engaged with, gaining benefits from this, which could be particularly valuable to low-income groups who are marginalised from housing choice. Holman and Rydin (2013) also stipulate that social capital is most effectively developed within the context of a clear organisational framework which encourages participation, stating that the process is more mediated within an organised framework.

McDougall and Banjade (2015) explore the links between resource management and social capital, explaining that the processes of co-ordination and co-operation lead to mutual gain, which in turn encourages social capital. This research implies a generally positive, closed 
system, where social capital provides group advantage through social networks and trust, which then develops (more) social capital and so on. However, external factors can negatively impact on social capital over time. For example, Menzel et al. (2013) considering long-term implications of participation, concluded that participation can erode social capital, highlighting that the quality of participation (e.g. measured by assessing the equality, appreciation of input and organisation of participation) is more important than the degree of participation (which can be assessed through the measurement of frequency and nature of participation) in relation to the effect on social capital. Similarly, McDougall and Banjade's study (2015) found that internal and external efforts to increase social capital (especially bridging social capital) can actually reinforce exclusion because marginalised members of the community who have less social capital have little influence over the decision-making processes, and avoid engagement with group management activities. Noterman (2016) also identifies that a shared resource does not necessarily increase social interaction or relationships, and states that it can cause erosion to social capital by limiting control to a minority. Therefore, whilst the physical act of sharing responsibilities does materially bring together residents, it is not conclusive that this necessarily leads to increased levels of social cohesion. However, Hammiduddin and Gallent $(2016,6)$ affirm that,

"There is clearly a strong link between act of production and communitarianism spirit as an outcome of group builds. Homes collectively create the setting for the interactions through which communities are constructed."

\subsection{Research Aim and Focus}

The research informing this paper set out to explore the role of affordable self-build housing projects to deliver socially sustainable communities, and assess their scope to address the lowincome housing shortage. We focused on specific (small-scale) affordable self-build housing projects in England and Wales to examine:

- how participation evolves through the process of self-build housing projects, with an aim to understand the positive and negative factors and 'feedback loops' between social cohesion (including social capital) and participation,

- whether social capital can be sustained over time in self-build affordable home projects and what are the determining factors that influence this; and

- the role social cohesion plays in self-build housing projects.

Our research did not attempt to evaluate the dynamics and relationship between a self-build community and the wider neighbourhood. 


\section{Methodology}

Owing to a lack of consistent theory and ambiguous results from existing studies on the effects that community-based projects have on social cohesion, social capital and participation, a Constructivist Grounded Theory (CGT) approach was used to inform theory based on empirical data analysis (Denscombe, 2014; Higginbottom and Lauridsen, 2014). The research process included primary and secondary data collection from self-build case studies, coding of empirical data and comparison between case studies, as well as between the selected case studies and the reviewed literature to elicit and assess how social interactions between people and social phenomena, such as sense of community, are constructed (Bryman, 2012; Creswell, 2014).

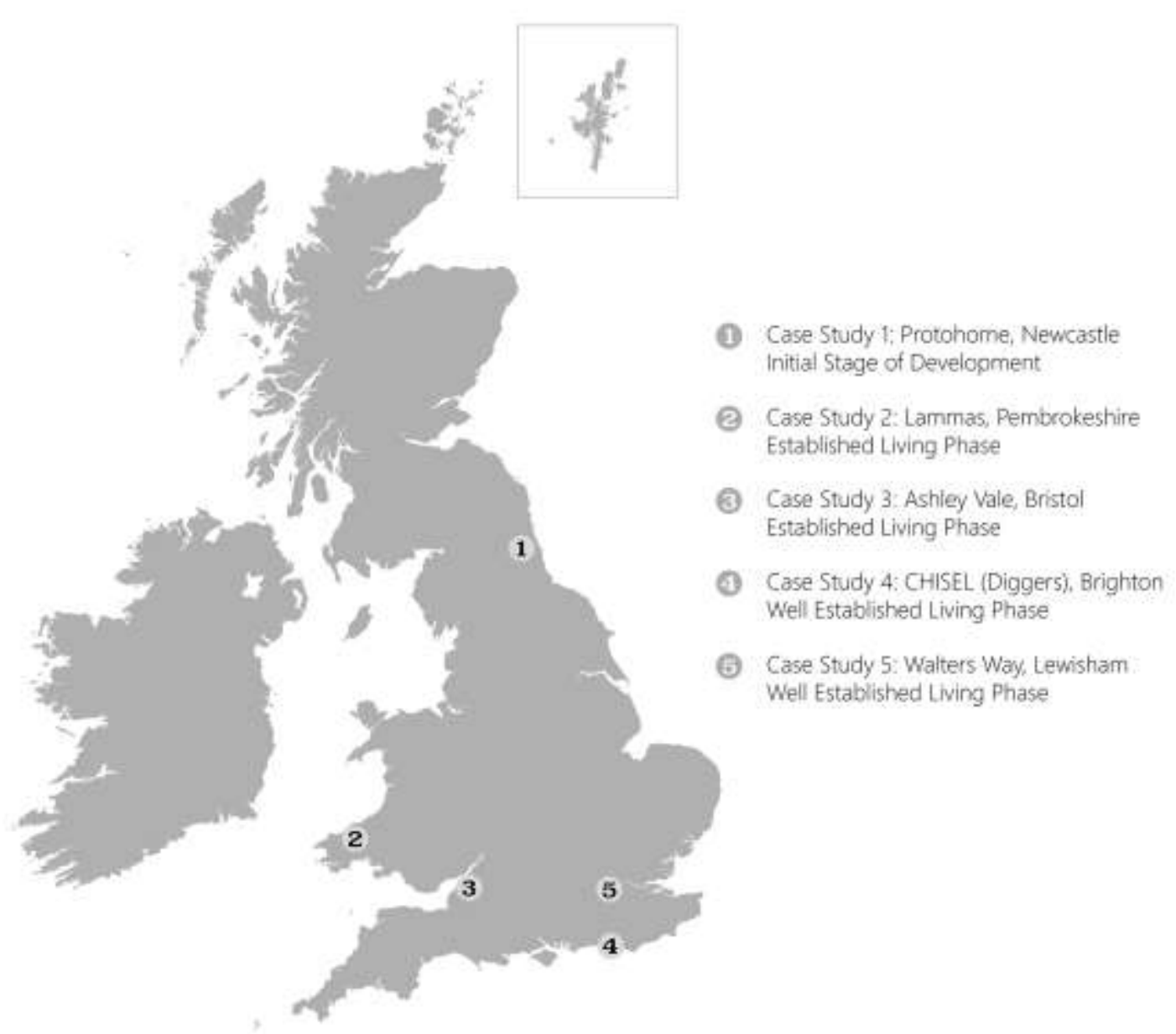

Figure 1: Map showing the distribution of the five case studies (one in Wales and four in England) 
Table 1: Description of the five case studies

\begin{tabular}{|c|c|c|c|c|}
\hline Case Study & Stage of Development & Method of Selection & Participant Identifier: Gender, Role & Key Characteristics \\
\hline Protohome $(\mathrm{PH})$ & $\begin{array}{l}\text { Initial Stage of Development: } \\
\text { experienced organisational } \\
\text { phase and prototype model } \\
\text { constructed }\end{array}$ & Online research & A-PH: F, project initiator/organiser & $\begin{array}{l}\text { Prototype self-build housing project, aiming to } \\
\text { provide shelter, support and skills to individuals } \\
\text { experiencing homelessness and/or with no or very } \\
\text { low income. Aims to create model which can be } \\
\text { replicated. }\end{array}$ \\
\hline Lammas (LA) & $\begin{array}{l}\text { Living Phase: experienced the } \\
\text { organisational phase and } \\
\text { construction phase }\end{array}$ & Online research & $\begin{array}{l}\text { A-LA: } F \text {, resident and founding } \\
\text { member } \\
\text { B-LA: } M \text {, resident and founding } \\
\text { member } \\
\text { C-LA: } M \text {, resident and founding } \\
\text { member }\end{array}$ & $\begin{array}{l}\text { Self-build community project with 'low-impact-living' } \\
\text { focus for which planning permission was granted in } \\
2006 \text {. Aims to design model which can be replicated. } \\
\text { By } 2017,9 \text { affordable houses were constructed / } \\
\text { under construction positioned around a community } \\
\text { hub. }\end{array}$ \\
\hline Ashely Vale (AV) & $\begin{array}{l}\text { Established Living Phase: } \\
\text { experienced the organisational } \\
\text { phase, construction phase and } \\
\text { communal living for } 6 \text { years }\end{array}$ & Online research & $\begin{array}{l}\text { A-AV: } F \text {, resident and founding } \\
\text { member } \\
\text { B-AV: } M \text {, resident and founding } \\
\text { member }\end{array}$ & $\begin{array}{l}\text { Community self-build project that was developed in } \\
\text { response to concerns over the redevelopment of a } \\
\text { former scaffolding yard rather than lack of low-cost } \\
\text { housing. The site was purchased in } 2001 \text { and since } \\
\text { then } 41 \text { homes have been constructed, of which } 6 \\
\text { units were originally classed as 'affordable housing'. } \\
\text { The housing has ecological and innovative designs, } \\
\text { with a community hub, and is deemed to be an } \\
\text { affordable way to enter the housing market. }\end{array}$ \\
\hline $\begin{array}{l}\text { CHISEL }(\mathrm{CH}) \text { (Diggers } \\
\text { and Greenstreet) }\end{array}$ & $\begin{array}{l}\text { Well-established Living Phase: } \\
\text { experienced the organisational } \\
\text { phase, construction phase and } \\
\text { communal living for } 20 \text { years }\end{array}$ & Snow-balling & $\begin{array}{l}\text { A-CH: M, founding member who } \\
\text { works for CHISEL; professional } \\
\text { experience of working with the } \\
\text { 'Diggers' project and personal } \\
\text { experience of 'Greenstreet' community } \\
\text { self-build project }\end{array}$ & $\begin{array}{l}\text { CHISEL is a neighbourhood housing association } \\
\text { which provides affordable housing. In the 1990s it } \\
\text { developed pioneering self-build co-operatives such } \\
\text { as 'Diggers' in Brighton and 'Greenstreet' in the } \\
\text { London Borough of Lewisham. }\end{array}$ \\
\hline Walters Way (WW) & $\begin{array}{l}\text { Well-established Living Phase: } \\
\text { experienced the organisational } \\
\text { phase, construction phase and } \\
\text { communal living for } 30 \text { years }\end{array}$ & Snow-balling & $\begin{array}{l}\text { A-WW: } M \text {, resident, but not a } \\
\text { founding member }\end{array}$ & $\begin{array}{l}\text { Pioneering self-build project initiated in } 1979 \text { by } \\
\text { Walter Segal and using his method of construction to } \\
\text { provide affordable housing. The local athority gave } \\
\text { residents a plot of land and were allowed to build } \\
\text { timber framed housing in an experimental site in } \\
\text { London to provide social housing with } 27 \text { houses } \\
\text { constructed. }\end{array}$ \\
\hline
\end{tabular}


Table 2: Interview questions and memo extracts

\begin{tabular}{|c|c|c|}
\hline $\begin{array}{l}\text { Case Study \& Date of } \\
\text { Interviews }\end{array}$ & Interview Questions & Extracts from Memos After Interviews - Reflection Process \\
\hline Lammas 24/09/2016 & $\begin{array}{l}\text { Reasons for starting project? How did levels of } \\
\text { participation and social cohesion evolve? How to apply } \\
\text { model on larger scale? }\end{array}$ & $\begin{array}{l}\text { Reoccurring themes: empowerment, importance of roles within the community, shared sense } \\
\text { of identity, sharing lifestyles... Shared long-term goals seem to be lacking? What happens } \\
\text { when self-build developments finish - what shared aims do they then have, what next? }\end{array}$ \\
\hline Protohome 02/11/2016 & $\begin{array}{l}\text { What was the trigger to start the project? How did } \\
\text { levels of participation and social cohesion evolve? } \\
\text { What roles did people play? Lessons learnt? How to } \\
\text { apply model on larger scale? }\end{array}$ & $\begin{array}{l}\text { Appears (as also seen in secondary research) that many of the low-income self-build projects } \\
\text { are in response to a crisis... There was a shared goal and there has to be involvement from all } \\
\text { members at the start... conflict was managed... Multi-level social networks - bridging social } \\
\text { capital... Social cohesion and participation increased. Provides sense of ownership, social } \\
\text { collective ownership... }\end{array}$ \\
\hline CHISEL 07/11/2016 & $\begin{array}{l}\text { Reasons for starting project? Levels of involvement of } \\
\text { participants at beginning of project? Roles which } \\
\text { people had? How did levels of participation and social } \\
\text { cohesion evolve? }\end{array}$ & $\begin{array}{l}\text { Shared vision developing theme...conflict can be overcome through shared vision / } \\
\text { goal...tensions are deep rooted...disillusion can happen when project takes time. }\end{array}$ \\
\hline Ashley Vale 12/12/2016 & $\begin{array}{l}\text { Reasons for starting project? Involvement of } \\
\text { participants at the start and throughout the process? } \\
\text { Shared visions goals? How did levels of participation } \\
\text { and social cohesion evolve? }\end{array}$ & $\begin{array}{l}\text { Shared vision is important in overcoming conflict at any stage of the } \\
\text { development...empowerment...sense of community...increase cohesion and participation. }\end{array}$ \\
\hline Walters Way 01/02/2017 & $\begin{array}{l}\text { Involvement of participants at the start and throughout } \\
\text { the process? Shared visions goals? How did levels of } \\
\text { participation and social cohesion evolve? Is there a } \\
\text { shared vision amongst the community? }\end{array}$ & $\begin{array}{l}\text { Initial peak in participation at start of project, developing social cohesion...community spaces } \\
\text { can provide areas to increase participation, increase social cohesion...in some cases cause for } \\
\text { conflict. }\end{array}$ \\
\hline
\end{tabular}


Four case studies were initially identified based on online searches using key words such as "affordable, community, self-build projects" and then selected based on the following criteria. Firstly, they expressed a common interest of self-build housing which was used as a lens for assessing participation, social capital and social cohesion. Secondly, each represented a different stage in the self-build process (the organisational phase before construction, construction, recent habitation and sustained communal living), providing an understanding and overview of the processes involved with self-build community construction. Thirdly, they claimed to provide affordable / 'low-cost' homes and participants needed some form of financial aid to access housing. Fourthly, the case studies were based in different regions of England, providing a range of geographical contexts which was considered to aid generalization. During the research, snowballing provided two additional case studies; and one of the originally selected case studies could not be taken forward beyond the secondary research stage due to non-response and lack of suitable participants to be interviewed, providing a total of five case studies. Figure 1 shows their locations and Table 1 lists their specific characteristics explaining additional selection reason(s) and case study characteristics, and the number and role of participants. At the time of case selection, these were the only sites which met the research criteria. Whilst five case studies are a relatively small selection of sites, this is still considered to provide an accurate representation of the social characteristics of affordable self-build housing in England and Wales because there are currently so few examples.

Eight semi-structured, in-depth interviews were conducted face-to-face or via telephone with members of the self-build communities between September 2016 and February 2017. Prior to the interview, respondents received the questions (see Table 2) and were asked to read and complete the informed consent form. All interviews were digitally audio-recorded and transcribed. During the research process, as themes emerged (such as 'shared vision') it was necessary to test some of the theories which emerged in order to develop these concepts further and also provide robust and reliable data. For example, the need for a clear management framework to facilitate and maintain levels of social cohesion only emerged during the interviews. As the interviews progressed, new themes that reoccurred were tested to see whether this was coincidental, or whether they had a direct relationship with social cohesion. The two additional case studies were useful here as the interviews were tailored to focus on these themes and helped test the emerging theories.

The initial coding of interviews was manually examining each transcript and allowing themes to develop from the research systematically. The coding, or labelling, of the data categorised the information into segments as patterns emerged from the data which were then interrogated (Charmaz, 2006), aided by thematic analysis, or 'driving themes from textual data' (AttrideStirling, 2001, 387). Where questions or contradictions in the data emerged, this was taken forward in future interviews to clarify and focus emerging patterns more succinctly. Axial 
coding (Strauss and Corbin, 1990) was used to develop a deeper level of abstraction of the gathered data to allow for the generation of theory. This essentially provided a network of data, where principles and meaning could be detected (Attride-Stirling, 2001). Memo-writing allowed data to be explored systematically alongside coding and provided the platform to develop theories from the information collected. Memo-writing also provided an opportunity for reflective consideration of the data gathered and contributed to the theory generation process (Charmaz, 2006). The codes and data were analysed several times until theoretical saturation was achieved to provide robustness to the analysis and aid clarity and coherence to the theoretical propositions. The key themes were also scored on a scale of 0 to 5 for each case study, with 0 meaning that no identifiers of the key themes were evident and 5 meaning that high levels of the indicators were evident.

\section{Research Findings and Discussion}

Table 3 presents a summary of the findings using the key themes from the literature review and associated characteristics (our 'identifiers') partly gleaned from case studies reported in the literature and partly emerging through the process of coding and analysis of the case study data. The identifiers were used to determine and score levels of social capital, participation and social cohesion and to capture the inter-relationships between the different concepts. During the process of coding shared vision and having a management framework emerged as important factors in assessing social capital, social cohesion and participation and their long-lasting impacts, and were therefore adopted as additional key themes. These two factors also to a large extent explain the lower scores for the Lammas project compared to the other four case studies.

\section{[INSERT Table 3: Overview of social sustainability identifiers and results of scoring the case studies]}

\subsection{How Self-build Affects Participation}

All case studies showed a clear initial peak in levels of participation amongst members during the organisational phase, evident in verbal engagement during meetings and emotional participation whereby relationships and "comradery" were formed. During this time, social bonding capital was established, creating social links between members of the community. All the participants identified that during this phase, they felt a sense of empowerment. These findings are unsurprising given that the opportunities for engagement are at their highest during this phase. Participant A-PH expressed the importance of developing community ties at the start of the housing project as follows: 
"...the process of building social ties are formed so that it's not only the building of a building, or the building of skills, education, employment opportunities, but actually it's a much more deeper form of creating social ties, confidence, social inclusion, which was at the heart of the project."

The reference to a "deeper form" of "social ties, confidence and social inclusion" highlight the importance of developing trust to enable the group to engage with each other more effectively. The high level of (constructive) participation is thus linked to trust-building which developed through meaningful relationships between members of the group. Protohome at the time of the interview only had experienced the organisation and building phases of the housing project with the memories fresh, but the results from the other case studies also support this theory. We scored Protohome 4/5 in relation to participation based on the high sense of empowerment reported during the interview and the effective management framework which gave direction but did not stifle engagement. Similar characteristics were also apparent in the CHISEL, and Ashley Vale case studies which also scored highly, but not in the Lammas case study, scoring 2/5 for participation.

The organisational phase can often be lengthy; for example, taking around four years in two of the case studies. During this time, relationships appear to have much more capacity to develop deeper bonds than they would be able to through traditional housing delivery, with increased emotional participation between members. Participant A-CH commented:

“...it was quite a heavy involvement. In the case of Greenstreet it was up to one meeting a week for a period of four years before actually getting on site, so it took a lot commitment."

The bonds created at the start of the project were thus found to be key to the effectiveness of long-lasting participation. However, disagreements and conflicts can arise during this intense organisational phase relating, for example, to the design and size of the dwellings, logistics and planning and personal disagreements. Therefore, whilst opportunities for participation can develop trust and meaningful relationships, this does not necessarily mean that that social cohesion will be positively impacted. Disagreements, sometimes regarding the way in which the project should be managed, or decisions over community spaces for example, provided deep rooted tensions, which in four out of the five case studies carried into the next phases of the selfbuild housing project. For example, Participant A-CH stated that:

“...the build process was so arduous there's also some, often quite deep seated, rifts between people and they continue on. So you get friendships that have a sense of looking after each other, like with that young woman whose mother died, but you also get people who find it really hard to talk to each other 'cause they spent years in meetings disagreeing with each other about how to do the build and that doesn't go away." 
Table 3: Social sustainability identifiers and results of scoring the case studies

\begin{tabular}{|c|c|c|c|c|}
\hline Key Concepts: & Social Cohesion & Participation & Social Capital & Shared Vision \\
\hline Key Identifiers: & $\begin{array}{l}\text { social order, conflict } \\
\text { management, sense of } \\
\text { community, participation / } \\
\text { engagement, involvement at the } \\
\text { start of the project }\end{array}$ & $\begin{array}{l}\text { trust, empowerment, } \\
\text { opportunities for engagement, } \\
\text { community space, management } \\
\text { framework }\end{array}$ & $\begin{array}{l}\text { empowerment, sense of community, } \\
\text { responsibility, shared emotional } \\
\text { connections, self-organisation, } \\
\text { bonding, leadership, management } \\
\text { framework }\end{array}$ & $\begin{array}{l}\text { shared purpose, empowerment, } \\
\text { cohesion }\end{array}$ \\
\hline Ashley Vale (AV) & $\begin{array}{l}\text { Score: } 4 \\
\text { Sense of community felt by } \\
\text { residents, participation between } \\
\text { residents in social and formal } \\
\text { occasions, heavy involvement at } \\
\text { start of project. }\end{array}$ & $\begin{array}{l}\text { Score: } 4 \\
\text { Multiple opportunities for } \\
\text { engagement, empowerment } \\
\text { identified, established management } \\
\text { framework. Trust not identified. }\end{array}$ & $\begin{array}{l}\text { Score: } 4 \\
\text { Empowerment identified, sense of } \\
\text { community felt by residents, shared } \\
\text { emotional connections, evidence of } \\
\text { self-organisation, bonding, leadership } \\
\text { and an established management } \\
\text { framework. Informal sharing of skills } \\
\text { and resources during self-build process; } \\
\text { communal gardening. }\end{array}$ & $\begin{array}{l}\text { Score: } 5 \\
\text { Shared vision at the start of the } \\
\text { process which was "refreshed" to } \\
\text { see if the aims had remained the } \\
\text { same or if they had changed and } \\
\text { followed through each stage of } \\
\text { the development. }\end{array}$ \\
\hline CHISEL (CH) & $\begin{array}{l}\text { Score: } 3 \\
\text { Sense of community felt, high } \\
\text { involvement at the start of the } \\
\text { project (which in some instances led } \\
\text { to disillusion), but facilitated } \\
\text { interaction and participation. } \\
\text { Evidence of disagreements / some } \\
\text { conflict throughout all project } \\
\text { phases, and inability to resolve } \\
\text { some of the disagreements. }\end{array}$ & $\begin{array}{l}\text { Score: } 4 \\
\text { Various opportunities for } \\
\text { engagement, e.g. social events, } \\
\text { community building and activities. } \\
\text { Reliance on other members of } \\
\text { community for help which indicates } \\
\text { trust. Empowerment identified } \\
\text { through sense of achievement. } \\
\text { Management framework dissolved } \\
\text { after organisation phase. }\end{array}$ & $\begin{array}{l}\text { Score: } 3 \\
\text { High levels of bonding initially, shared } \\
\text { emotional connections, sense of } \\
\text { community, empowerment, self- } \\
\text { organisation, leadership, but the high } \\
\text { levels of bonding and sharing } \\
\text { decreased after the organisational } \\
\text { phase. }\end{array}$ & $\begin{array}{l}\text { Score: } 4 \\
\text { A common vision evolved } \\
\text { (accidentally rather than planned) } \\
\text { as part of being involved with the } \\
\text { self-build process. This did not } \\
\text { always mean positive } \\
\text { relationships, but created a sense } \\
\text { of shared community. }\end{array}$ \\
\hline
\end{tabular}

Scoring: 1 = little or very weak signs; 2 = partial or weak signs; $3=$ moderately strong signs; $4=$ some strong signs; $5=$ strong and consistent signs 
Table 3: Social sustainability identifiers and results of scoring the case studies cont.

\begin{tabular}{|c|c|c|c|c|}
\hline Lammas (LA) & $\begin{array}{l}\text { Score: } 1 \\
\text { Lack of social order, disagreements } \\
\text { about how to manage the } \\
\text { community and assets, participants } \\
\text { stated that some of the residents } \\
\text { wanted to have a better sense of } \\
\text { community and dissatisfied with } \\
\text { levels of cohesion. Low levels of } \\
\text { participation between members of } \\
\text { the community. }\end{array}$ & $\begin{array}{l}\text { Score: } 2 \\
\text { Members of the community actively } \\
\text { live within the village without having } \\
\text { to participate with others at all. } \\
\text { Some opportunities for participation } \\
\text { provided by the communal sharing } \\
\text { of services and the community hub. } \\
\text { Little sense of trust between } \\
\text { members of the community, some } \\
\text { evidence of empowerment. }\end{array}$ & $\begin{array}{l}\text { Score: } 2 \\
\text { Some sense of empowerment and } \\
\text { sense of community. No sense of } \\
\text { shared emotional connections, bonding } \\
\text { or leadership. Lack of effective } \\
\text { management framework. Self- } \\
\text { organisation evident, but in isolation. } \\
\text { Responsibility felt, but not collectively. }\end{array}$ & $\begin{array}{l}\text { Score }=1 \\
\text { One of the participants explicitly } \\
\text { stated that there was no shared } \\
\text { ethos, another stated that there } \\
\text { was a shared vision, but very little } \\
\text { evidence to support this. }\end{array}$ \\
\hline Protohome (PH) & $\begin{array}{l}\text { Score: } 4 \\
\text { High level of involvement at start of } \\
\text { project, some social disorder which } \\
\text { was overcome, sense of community } \\
\text { high (family like ties), participation, } \\
\text { strong bonds. }\end{array}$ & $\begin{array}{l}\text { Score: } 4 \\
\text { Trust developed between members } \\
\text { of the community who were offered } \\
\text { opportunities for engagement } \\
\text { through the process of organisation. } \\
\text { High sense of empowerment, } \\
\text { management framework. }\end{array}$ & $\begin{array}{l}\text { Score: } 5 \\
\text { High level of empowerment, sense of } \\
\text { community, responsibility, deep shared } \\
\text { emotional connections, self- } \\
\text { organisation, bonding, leadership and a } \\
\text { management framework. }\end{array}$ & $\begin{array}{l}\text { Score: } 5 \\
\text { Shared sense of purpose, } \\
\text { empowerment and cohesion. }\end{array}$ \\
\hline Walters Way (WW) & $\begin{array}{l}\text { Score: } 4 \\
\text { Good level of social order, } \\
\text { acknowledges that not everyone } \\
\text { gets along all the time. There is a } \\
\text { sense of community, participation } \\
\text { and there was involvement by } \\
\text { residents at the start of the project. }\end{array}$ & $\begin{array}{l}\text { Score: } 3 \\
\text { Various mechanisms for } \\
\text { engagement, empowerment, sense } \\
\text { of trust. There is no communal } \\
\text { space and there is no formal } \\
\text { management structure. Regular } \\
\text { informal and formal social events } \\
\text { and an AGM. }\end{array}$ & $\begin{array}{l}\text { Score: } 3 \\
\text { Sense of empowerment, sense of } \\
\text { community, shared emotional } \\
\text { connections, self-organisation, bonding. } \\
\text { Unable to clarify level of responsibility } \\
\text { of individuals during construction } \\
\text { process or afterwards, no management } \\
\text { structure. Participants speaks of regular } \\
\text { meetings with neighbours, increase of } \\
\text { social cohesion over last } 10 \text { years, } \\
\text { original owners coming back to visit - } \\
\text { lasting relationships. }\end{array}$ & $\begin{array}{l}\text { Score: } 4 \\
\text { Shared rules, sense of } \\
\text { empowerment and cohesion. }\end{array}$ \\
\hline
\end{tabular}

Scoring: 1 = little or very weak signs; 2 = partial or weak signs; $3=$ moderately strong signs; $4=$ some strong signs; 5 = strong and consistent signs 
Participatory approaches are thus an expression of the intensity of the relationships which are formed, with positive and negative consequences for social cohesion within a community. The depth of the bonds which are created lead to relationships which may continue into later phases, positively (or negatively) affecting participation and social cohesion. This finding emerged early in the case study work and was consequently tested with other case studies which all supported this observation.

All participants stated that self-build projects can increase participation amongst members of the community in the form of self-organisation, engaging in social events and the management of resources. Interviewees identified that participation varied during the 'building phase' and generally decreased in the 'living phase', which was most pronounced for Lammas with the decreased need for frequent meetings and communal decision-making being influential factors. For example, after planning permission was granted for the Lammas project, there was limited sharing of resources and skills during the construction phase which was a very individual process, compared to the Protohome or Ashley Vale projects, where there was more active participation between residents. Most of the self-build communities assessed as part of this project have sustained methods to allow participation during the "living phase", with formal events such as Annual General Meetings (AGMs), community gardening, social events and activities in community spaces. This is reflected by their higher scores and suggests that actively managing the opportunities for engagement maintains levels of participation amongst community members.

The existence of physical social sustainability factors such as dedicated community places (as in the case studies $\mathrm{CH}$, LA and $\mathrm{PH}$ ) facilitated non-physical social sustainability factors such as participation. The shared spaces provided a platform for continued interaction between residents following the organisational phase. Walters Way does not have a shared inside communal space, which Participant A-WW suggested was "a failing" of the project but that such space would be beneficial on a practical and social level. However, the collective management of the communal garden allowed members to be involved in the shared aim of improving their outside common space(s) through community engagement. Also the private road they manage acts as a commons, where children play and members of the community hold informal BBQs and social events. Participation by and interaction between members of the community led to 'group advantage' (Coleman, 1988) beyond the initial organisational and building phases of the self-build project, highlighted by indicators such as social capital and social cohesion. Therefore, communal physical spaces can act as useful platforms to increase opportunities for residents to participate, but they are not necessarily key to the development of participation, which can be achieved in a variety of ways. 
This is further illustrated where the presence of communal spaces and participatory events bring out disagreement and conflict (regarding the design and scale of the building/spaces and uses) rather than facilitate social cohesion. For example, at Lammas the community hub is a space of much contention owing to the disagreements between residents about how the hub should be constructed and managed. Two of the participants identified the mixed impacts which the community hub created; in the words of Participant B-LA:

“...the hub is fascinating, cause I think it's very much where we, it's symbolically and physically where we've really come together, but it's also where we've really come apart. That's where you can see a difference in actual ethos."

Therefore, communal spaces can have positive or negative consequences on participation and social cohesion. In the Lammas case study, the lack of shared ethos or formal management of the community hub could explain why these conflicts have emerged and persisted.

\subsection{How Self-build Affects Social Capital}

Self-build provides the opportunity for self-organisation of an individual, but also as a group, which is made stronger through the bonds which develop between people during the stages of interaction. In our case studies, social capital peaked at the start of the projects, evidenced by a sense of empowerment and achievement acknowledged by participants (see Figure 2). The physical acts of sharing resources, knowledge and skills actively facilitated increased levels of social capital during the organisational and (to a degree) continuing into the building phases for collective gain and developed a variety of levels of bridging capital such as between the communities and the Local Authority, and also between individuals and professionals such as carpenters and architects For example, Participant A-CH observed that:

“... you build up a lot of capital from that - of links between people..."

Furthermore, Participant A-AV commented that during the building phase,

"Everyone was in charge of their own plot, but there were definitely times when people helped each other out."

Although the organisational phase developed social capital, with time some participants mentioned feelings of disillusion with the process; some members dropped out or became fatigued, leading to an erosion in social bonding capital. Furthermore, social bridging capital was eroded in the Lammas project which had received vehement opposition from local residents and the Local Authority. Therefore, we argue that the group advantage gained during the selfbuild organisational phase should be understood as being 'potentially fragile'. Without the means (e.g. conflict and/or resource management structures) in place to ensure that disputes can be overcome and/or adequate support offered and adjustments made if delays occur, erosion of 
social capital can easily occur; and this is of particular relevance for the organisational phase. Furthermore, particularly bonding social capital can be significantly worn away when members of the community drop out of the process and/or when deep-rooted tensions develop between members of the community. Bridging social capital also appeared to be easily eroded past the organisational phase as the communities had less need to liaise with the Local Authorities for example.

In all five projects participants acknowledged that conflicts can arise and lead to entrenched disagreements. However, some also commented how this is "normal" and likened these relationships to family dynamics, suggesting that differences in opinion, interests or priorities need not necessarily lead to a significant erosion of social cohesion, despite some tensions. Furthermore, four of the case studies found ways to overcome conflict or disagreements, building on the existing relationships and ensuring the social capital and participation were maintained, in spite of these differences. For example, when talking about how members of the Greenstreet project decided to landscape the communal space, Participant A-CH commented:

"It was interesting because there were some people involved in that who in some ways had less good relationships with each other, but as a group they managed that and some of those were key people in making the garden together, so they overcame those differences to do it."

This quote also highlights the importance of a shared vision or goal. Our research found that where a self-build community had a shared purpose and/or kept refreshing shared goals, they were able to resolve tensions and built social capital to deliver outcomes of mutual gain. Thus, joint visioning and defining communal goals improve social cohesion and are important beyond the initial goal of establishing self-build homes. Furthermore, participation is facilitated through this group purpose; triggering engagement in social gatherings and formal and informal activities (e.g. gardening, BBQs, parties, AGMs) - which can increase bonding, emotional connections and sense of community. We therefore postulate that a shared vision / visioning is important in maintaining social capital.

\subsection{How Self-build Affects Social Cohesion}

Having a shared purpose also has a positive impact on social cohesion; all the interviewees noted that initially there was a sense of shared vision - this ranged from developing eco-friendly homes, producing a self-sufficient village, to providing improved housing to meet the needs of a community. Each community had a shared purpose, which was defined at the start of the project and provided a common focus, which increased communal actions and shared emotional connections and thereby increasing their sense of community and social cohesion during the initial phase of the self-build housing project. 
Following on from completion of the self-build homes, the case studies entered the "what now?" stage; many of the participants spoke about how they questioned the purpose of their community as they moved into the living phase. Participant B-LA spoke about tensions and that members of the Lammas community felt that there was a lack of community spirit, which was supported by Participant A-LA and secondary research. Participant B-LA also spoke about completing the initial project objective and their thoughts about what came after this:

"So, we're kind of looking at each other and going what now?"

This quote, and various statements by the other two interviewees, indicated that in the Lammas case study, the lack of a focus and purpose appeared as soon as the organisational phase ended, perhaps because their initial objective had been hard in achieving. There appeared to be a general lack of direction for the Lammas community as a whole. The absence of a shared longterm vision or refreshed visioning seems to have led to a decrease in the levels of social cohesion, and reduced participation, which was expressed as a sense of isolation felt by some residents and conflicts evident regarding the management of community spaces. Participant CLA stated that there is a shared perspective, however, the explanations focused on physical objects/infrastructure which members of the community share, such as water and electricity, but differs from shared emotional values. Also, when Participant C-LA was asked whether there is social cohesion, the interviewee responded with "mostly". The participant also made few references to the relationships between members of the community and admitted that there were members who had struggled to socially integrate into the community, but did not elaborate why this was.

We scored Lammas the lowest, 1/5, for social cohesion due to the lack of social order, participation and sense of community. The remaining case studies, with higher scores for social cohesion (either $3 / 5$ or $4 / 5$ ), all displayed a shared vision. The shared vision was evident from the start of each project and was maintained usually via a management framework, along with the associated deep emotional ties which the organisational phase developed (but was not evident in the Lammas case study). Participant B-LA commented:

"...we are not sharing the same values or not in the same value systems..."

"There is no shared intension, there is no actual residents' organisation ..."

“...its [Lammas's] mission statement is to establish a flourishing network of ecovillages around the UK and possibly around the world. It says nothing about running an eco-village, it says nothing about the social structure of that ecovillage or anything like that. So, erm, it's the big gap essentially in the Lammas template."

In comparison, Participant A-AV explained that: 
"...once the site was finished it [the self-build co-operative] changed into the management company for the site ... we decided to refresh the aims and see if we had a different vision now that the project is finished, which is still in progress."

Of the chosen case studies, Ashley Vale had the most formalised social structure, with a management company that oversees the running of the communal space. Using a formal management framework, and through means of (participatory) communication tools such as emails and notice boards, the management company provided the platform to maintain and manage social relationships. A similar system was used in the Protohome project, where means to actively engage with other members of the group and to overcome challenges included group discussion sessions which focused on emotional concerns and practical skills lessons from professionals.

Discussing the lessons learnt from the Lammas project, participant B-LA was very clear that they had "no regrets" about the way in which the community had evolved and the community structure, but acknowledged that having a social structure and defining this at the start of the project could have increased social cohesion. This was also supported by comments from Participants A-LA and C-LA who explained that the community had explored various social structures to attempt to find one which satisfied their requirements, including inviting external mediators to carry out management workshops within the village. This indicates the importance of having some form of social structure in place from the start of the project.

\subsection{Social Sustainability Considerations throughout the Evolution Phases of Self-build Projects for Low-income Groups}

The above assessment of the key concepts and their associated identifiers were used to construct a diagram to summarise the findings from our case study research. Figure 2 highlights key factors and theory-informing points in relation to aspects of social sustainability, showing the fluctuating levels of participation, social cohesion and social capital throughout the evolution of self-build projects and the positive and negative influences.

In terms of the early phases of self-build, we explored the assumption that communal self-build projects increase levels of participation because they provide a platform for physical and emotional engagement with the planning process, and this provides opportunities for bonding to occur between people who share a common interest, (as found in various case studies; e.g. Coleman, 1988; Hammiduddin and Gallent, 2016). Our research findings show that the desire to achieve mutual gain increases these relationships and provides deep, long-lasting connections between members of the community who build trust and feel deeply empowered by the process. Critical assessment of the data found that forming these deeper level bonds increased the intensity of relationships, developing "family-like" ties and shared experiences, which can 
provide increased levels of social cohesion. In the example of Protohome, the experiences of homelessness allowed the members to develop closer, longer lasting relationships. Nevertheless, the intense nature of the organisational phase can also have negative consequences when tensions arise regarding fundamental decisions on design or shared spaces. Therefore, participation quite clearly can have positive and destructive consequences on social cohesion and social capital, which dispels the positivist portrayal of participation (Ha, 2007; Ahmad and Abu Talib, 2016) and supports existing research by Noterman (2016).

Evidence from all five case studies highlights the pivotal aspect of having a form of social structure or communal management system in place. This allows (or requires) members to continue to participate and acts as a conflict resolution process, which in turn can help maintain and increase social cohesion over time. Holman and Rydin (2013) suggest that having a clear structure allows for effective participation, when actually, the analysis of the interviews suggest that a form of social structure is vital in ensuring that in the context of self-build housing, conflict can be managed, and a shared vision is maintained. This could be explained by the fact that without a shared sense of common purpose, individuals lose the emotional connections which they had at the start of the self-build process. Moreover, when the group vision begins to diverge or if there is no management structure to facilitate reconciliation following conflict, combined with low levels of social capital, social cohesion is detrimentally affected. The fact that Ashley Vale, CHISEL, Protohome and Walters Way, which we scored 4/5 for a shared vision, had much more cohesive communities supports this theory. Similarly, the characteristics within the Lammas project, showing a lack of such shared management structure and visioning, and which we scored $1 / 5$, further supports this.

Self-build also affects social capital which, as postulated in existing research, was found to peak during the organisational phase, enabled through acts of resource sharing and self-organisation to achieve mutual gain. Sense of community appeared to closely relate to increased social cohesion; this is only touched upon in existing research as an effect of, rather than an indicator of, social cohesion (Kearns and Forrest, 2001; Cheung and Leung, 2011). There is some debate in the existing literature whether communal spaces or activities can increase participation (Kearns et al., 2014; Huron, 2015; Noterman, 2016). In this study, we found 'spaces' and 'activities' were important for social capital to grow. However, communal spaces and events were also found to be sources of tension, where conflicts regarding their use or management can erode social cohesion (e.g. at Lammas). However, with a clear shared vision for communal spaces, maintained via a management structure, such conflicts could be overcome (e.g. at CHISEL).

Our research did not explore how the individual characteristics of members of the community affect levels of social cohesion, social capital and participation, but these may of course be 
relevant factors. Participant B-LA touched on the fact that each member of the Lammas community is strong-minded and has set ideals about the ways in which they want to manage certain parts of the eco-village; this could be part of the reason why there were lower levels of social cohesion experienced by the residents. These psychological and sociological aspects could provide a useful and informative angle for future research.

Participants were asked about the barriers to self-build. Responses clarified that the financial implications were not considered to be significant, and that within the context of England land supply was one of the main problems holding back development. If the issue of land supply can be addressed, self-build housing could provide a means to deliver more affordable housing. Furthermore, existing research shows that the CHISEL model employing a housing association to initiate and fund self-build housing has been successful in delivering long-term low-cost housing (Ospina, 1992).

All the interviewees agreed that self-build could provide additional affordable housing and identified that affordable housing was their primary motive for initiating or taking part in the self-build projects. The interviews with Ashely Vale and Lammas project participants also highlighted other intensions such as to promote low-impact living or the threat of speculative house builders; however, accessibility to housing was a key incentive. Thus, all our case studies were triggered by the goal to provide affordable housing, usually in response to a threat or steadily rising costs to access the existing housing market, leading to the formation of a new community. In the words of Participant A-AV:

"I think it was the threat and opportunities together which galvanized people.

$[\ldots]$ house prices have already trebled since we started, at least."

Not all the housing which was assessed in this study, however, remain affordable owing to a lack of funding or lack of control regarding the ownership of the properties. At Ashley Vale, for example, the residents were unable to find a replacement housing association who wished to take on the management of the affordable housing properties after the original association went bankrupt. The dwellings therefore had to be sold to private occupiers for the full market value. This highlights the fragile nature of the affordable / low-cost housing market and trend seen in recent years for the sale of social housing for full market value. This impacts on the make-up of communities and social sustainability, with low-/no-income residents (potentially) being priced out of an initially low-cost housing community. 


\section{Figure 2: The effect of self-build housing projects on social cohesion, social capital and participation}

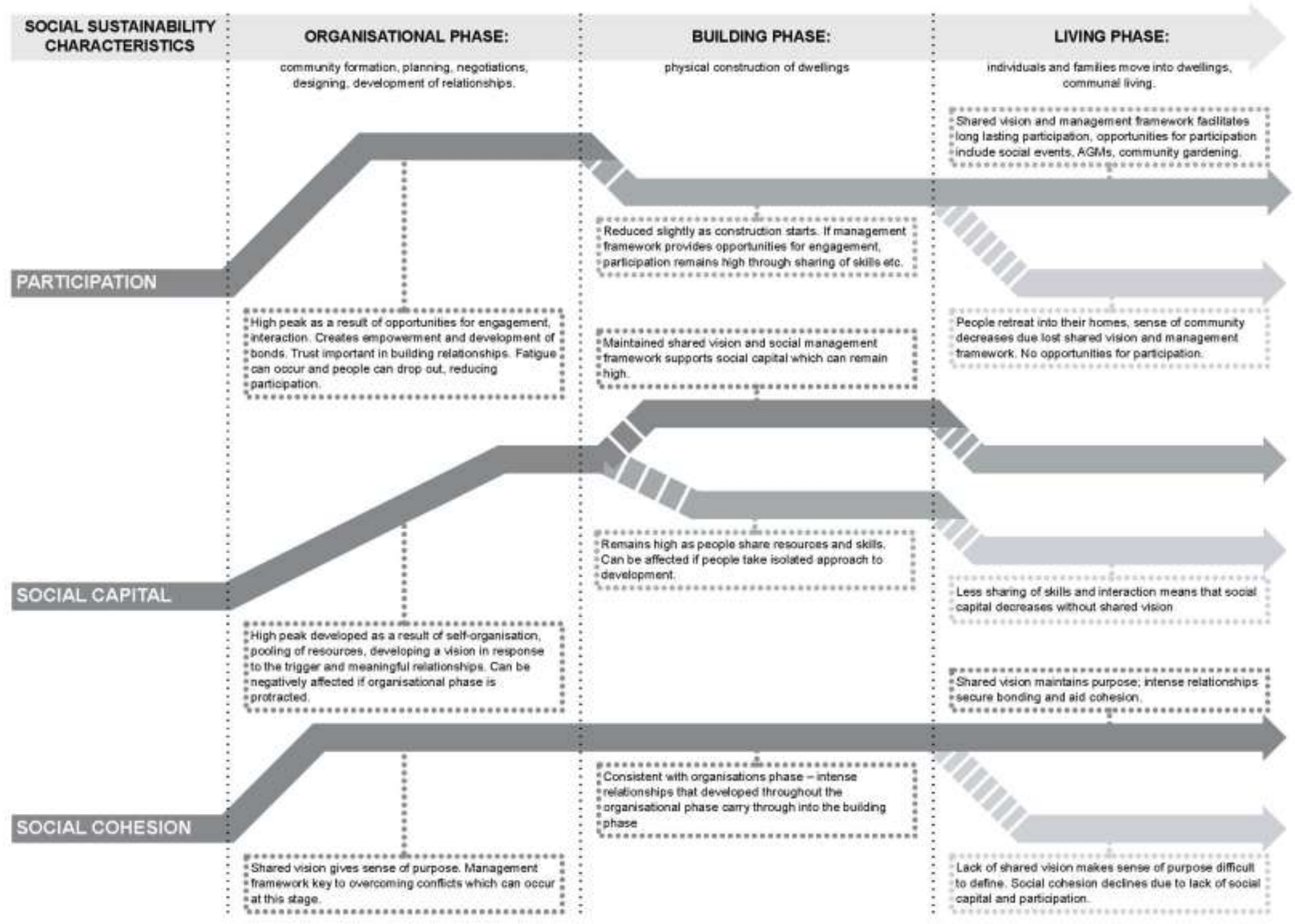




\section{Conclusions}

International research indicates that whilst there are differences in approaches, management and policies towards self-build housing, an interest in and research on social capital, cohesion and participation relating to communal self-build housing projects appears relevant across developed and developing nations, providing a common strand of interest. This paper explored the role self-build housing projects have in contributing towards social sustainability, through the examination of whether social capital can be sustained over time, and the positive and negative 'feedback loops' between social cohesion (including social capital) and participation. The case studies discussed offer valuable insight into the way in which low-cost self-build community projects were initiated and how they evolved over time, which, to our knowledge, has not been done within a UK context. In this final section we summarise the key findings in response to our research objectives and draw some general conclusions on the prospect of and (policy) support for self-build housing for low-income groups.

Firstly, with regard to participation and the positive and negative factors and 'feedback loops' between social cohesion (including social capital) and participation, the presence (or absence) and characteristics of communal spaces (including physical and virtual 'spaces' of interaction, communication and joint ventures), the individual characters/interests of the self-build residents (which we did not pursue to unpack in our study), and the adoption and characteristics of a management framework from the start to beyond the construction phase emerged as relevant factors. The importance of having a management framework and defining shared goals to provide direction for participation and aid social cohesion, to our knowledge, has not been explicitly covered previously and emerged unexpectedly as a significant factor in our research.

Secondly, in relation to whether social capital can be sustained over time in self-build affordable home projects and the determining factors that influence this, the research and interview data illustrated that self-build communities can, with an effective management framework and a sustained collective shared vision, facilitate increased levels of participation and social cohesion, and maintain social capital from the conception of a self-build project to its construction and living phases. There is however, likely to be a drop in social capital after the construction phase unless new communal 'projects' are visioned and delivered. Existing research indicates that social cohesion can provide more resilient, sustainable communities (Townsend et al., 2015; Blanco and Leon, 2017). Therefore, it can be purported that given the right social dimensions (as outlined above), self-build housing projects can provide more socially sustainable communities. 
Thirdly, regarding the role social cohesion plays in self-build housing projects, in line with Noterman (2016), we found that the intensive and sometimes prolonged organisational and construction phases can in some cases negatively affect social cohesion due to clashes in character and priorities and erode social capital and social cohesions. The significance of such conflicts and topics of debate could be an interesting point for further research. On the other hand, the intensity of the organisational and building phases and with useful formal or informal conflict management structures in place, deep lasting bonds can develop which positively affect participation and social cohesion. However, the bonding social capital generated between members of the self-build communities from the initial phases is fragile and can easily be eroded. The evidence of bridging social capital was not as apparent; however, this could have been because the research did not attempt to explore the external or vertical relationships between members of the community and other individuals or organisations, and this could be explored in future.

Finally, with regard to the international crises of housing for low/no-income groups, self-build already provides housing for some low-income communities in many developing and developed countries, but the UK seems to lag behind. Self-build projects, at least in the UK, seem to benefit from (if not rely on) the support of visionary housing groups / project members in supporting the process through the organisational and building phases. The delivery of sustainable and long-lasting housing solutions is of paramount importance across the world and self-build has already been recognised as an effective means of providing shelter (Sullivan and Ward, 2011; Soliman, 2012). Although none of the interviewees explicitly identified social cohesion, social capital or participation as motivations for starting the projects, these were clear positive effects associated with this method of housing delivery, when coupled with certain social influences such as a management framework and shared vision. If this example of housing delivery can provide more sustainable communities, as this and other research studies indicate, then this should be encouraged by Governments internationally. Adequate support is required, especially in terms of land supply in the UK (and property rights, information, skills training, access to funding etc. more generally). Self-build housing also fits well with the global movement towards decentralisation, making self-build housing a relevant and realistic part in creating sustainable communities. 


\section{References}

AHMAD, M.S. and ABU TALIB, N.B. (2016), Analysis of community empowerment on projects sustainability: Moderating role of sense of community. Social Indicators Research, 129, 1039-1056.

ATTRIDE-STIRLING, J. (2001), Thematic networks: an analytic tool for qualitative research. Qualitative Research, 1, 385-405.

BENSON, M. (2015), The social in self build [pdf]. London: Goldsmiths. Available at: http://www.gold.ac.uk/sociology/research/researchprojects/self-building/ (accessed 7 October 2015).

BLANCO, I. and LEON, M. (2017), Social innovation reciprocity and contentious politics: Facing the socio-urban crisis in Ciutat Meridiana, Barcelona. Urban Studies, 54, $2172-$ 2188.

BRAMLEY, G. (2016), Housing need outcomes in England through changing times: demographic, market and policy drivers of change. Housing Studies, 31, 243-268.

BREDENOORD, J. and VAN LINDERT, P. (2010), Pro-poor housing policies: Rethinking the potential of assisted self-help housing. Habitat International, 34, 278-287.

BRYMAN, A. (2012), Social Research Methods. 4th edition, Oxford: Oxford University Press.

MENZEL, S., BUCHECKER, M. and SCHULZ, T. (2013), Forming social capital - does participatory planning foster trust in institutions? Journal of Environmental Management, 131, 351-362.

CARTER, T. (1997), Current practises for procuring affordable housing: The Canadian context. Housing Policy Debate, 8, 593-631.

CHARMAZ, K, (2006), Constructing Grounded Theory: A Practical Guide Through Qualitative Analysis. London: Sage.

CHEUNG, C. and LEUNG, K. (2011), Neighborhood homogeneity and cohesion in sustainable community development. Habitat International, 35, 564-572.

COLEMAN, J.S. (1988), Social capital in the creation of human capital. American Journal of Sociology, 94, S95-S120.

CRAWFORD, P., KOTVAL, Z. and RAUHE, W. (2008), Social capital development in participatory community planning and design. Town Planning Review, 79, 533-553.

CRESWELL, J.W. (2014), Research Design: Qualitative, Quantitative, and Mixed Methods Approaches. Fourth international student edition. London: Sage.

DEMPSEY, N. (2009), Are good-quality environments socially cohesive?: Measuring quality and cohesion in urban neighbourhoods. Town Planning Review, 80, 315-345.

DEMPSEY, N., BRAMLEY, G., POWER, S. and BROWN, C. (2009), The social dimension of sustainable development: Defining urban social sustainability. Sustainable Development, 19, 289-300. 
DENSCOMBE, M. (2014), The Good Research Guide: For Small-scale Research Projects. 5th edition. Maidenhead: Open University Press / McGraw Hill Education.

DEPARTMENT FOR COMMUNITIES AND LOCAL GOVERNMENT (DCLG) (2011), Laying the Foundations: A Housing Strategy for England. London: Department for Communities and Local Government.

DEPARTMENT FOR COMMUNITIES AND LOCAL GOVERNMENT (DCLG) (2012), The National Planning Policy Framework. London: Department for Communities and Local Government.

DEPARTMENT FOR COMMUNITIES AND LOCAL GOVERNMENT (DCLG) (2016), Housing and Planning Act 2016. London: Department for Communities and Local Government.

DEPARTMENT FOR COMMUNITIES AND LOCAL GOVERNMENT (DCLG) (2017), Housing White Paper: Fixing Our Broken Housing Market, London: Open Government Licence.

DORLING, D. and REES, P. (2003), A nation still dividing: The British census and social polarisation 1971-2001. Environment and Planning A, 35, 1287-1313.

GARCIA, M. and HADDOCK, S.V. (2016), Housing and community needs and social innovation responses in times of crisis. Journal of Housing and the Built Environment, 3, $1-15$.

GULLINO, S. (2008), Mixed communities as a means of achieving sustainable communities: A comparison between US experiences and UK policy intensions. Local Economy, 23, 127 135.

HA, S.-K. (2007), Housing regeneration and building sustainable low-income communities in Korea. Habitat International, 31, 116-129.

HA, S.-K. (2008), Social housing estates and sustainable community development in South Korea. Habitat International, 32, 349-363.

HAMIDUDDIN, I. and GALLENT, N. (2016), Self-build communities: the rationale and experiences of group-build (Baugruppen) housing development in Germany. Housing Studies, 31, 365-383.

HIGGINBOTTOM, G. and LAURIDSEN, E. (2014), The roots and development of constructivist grounded theory. Nurse Researcher, 21, 8-13.

HOLMAN, N. and RYDIN, Y. (2013), What can social capital tell us about planning under Localism? Local Government Studies, 39, 71-88.

HOMEBUILDING AND RENOVATING MARKET RESEARCH (2013), UK Self-build Market Report. [pdf] Homebuilding and Renovating. Available at: http://www.selfbuildportal.org.uk/technical-downloads/category/5-other-reportsstats\#anchor-24 (accessed 22 April 2017).

HURON, A. (2015), Working with strangers in saturated space: reclaiming and maintaining the urban commons. Antipode, 47, 963-979. 
KEARNS, A. and FORREST, R. (2001), Social cohesion, social capital and the neighbourhood. Urban Studies, 38, 2125-2143.

KEARNS, A., BAILEY, N., GANNON, M., LIVINGSTON, M. and LEYLAND, A. (2014), 'All in it together'? Social cohesion in a divided society: Attitudes to income inequality and redistribution in a residential context. Journal of Social Policy, 43, 453-477.

LAMMAS (2016), Welcome to Lammas. Available at: http://lammas.org.uk/ [accessed 22 April 2017].

LANDMAN, K. and NAPIER, M. (2009), Waiting for a house or building your own? Reconsidering state provision, aided and unaided self-help in South Africa. Habitat International, 34, 299-305.

LAURENCE, J. (2011), The effect of ethnic diversity and community disadvantage on social cohesion: a multi-level analysis of social capital and interethnic relations in UK communities. European Sociological Review, 27, 70-89.

LEHTONEN, M. (2004), The environmental-social interface of sustainable development: capabilities, social capital, institutions. Ecological Economics, 49, 199-214.

MAHJABEEN, Z., SHRESTHA, K.K. and DEE, J.A. (2009) Rethinking community participation in urban planning: The role of disadvantaged groups in Sydney Metropolitan Strategy. Australasian Journal of Regional Studies, 15, 45-63.

MALIENE, V., HOWE, J. and MALYS, N. (2008), Sustainable communities: Affordable housing and socio-economic relations. Local Economy, 23, 267-276.

MCDOUGALL, C. and BANJADE, M.R. (2015), Social capital, conflict, and adaptive collaborative governance: Exploring the dialectic. Ecology and Society, 20, 44.

MCMILLAN, D.W. and CHAVIS, D.M. (1986), Sense of community: A definition and theory. Journal of Community Psychology, 14, 6-23.

NaSBA (2011), An Action Plan to Promote the Growth of Self Build Housing [pfd]. Available at:

http://www.google.co.uk/url?sa=tandrct=jandq=andesrc=sandsource=webandcd=1 andcad $=$ rjaanduact $=8$ andved $=0$ ahUKEwjR-

fDasuvJAhVGnw4KHcnFAiYQFggdMAAandurl=http\%3A\%2F\%2Fwww.buildstore.co.u k\%2FActionPlan\%2FGovt-Action-Plan-July2011.pdfandusg=AFQjCNHgyWJuxn_qUGXEK_OzYF5KE7LMA (accessed 22 April 2017).

NOTERMAN, E. (2016), Beyond tragedy: Differential commoning in a manufactured housing cooperative. Antipode, 48, 433-452.

OSPINA, J. (1992), Self-build for Rent: Choice, High Standards and Affordability. London: CHISEL.

PUTNAM, R. (2001), Bowling Alone: The Collapse and Revival of American Community. New York: Simon and Schuster. 
PUTNAM, R.D., LEONARDI, R. and NANETTI, R.Y. (1993), Making Democracy Work: Civic Traditions in Modern Italy. Princeton: Princeton University Press.

SAEGERT, S. and WINKEL, G. (2004), Crime, social capital, and community participation. American Journal of Community Psychology, 34, 219-233.

SEYFANG, G. (2010), Community action for sustainable housing: Building a low-carbon future. Energy Policy, 38, 7624-7633.

SOLIMAN, A.M. (2012), The Egyptian episode of self-build housing. Habitat International, 36, 226-236.

STRAUSS, A. and CORBIN, J. (1990), Basics of Qualitative Research: Grounded Theory Procedures and Techniques. Newbury Park, CA: Sage Publications.

SULLIVAN, E. and WARD, P.M. (2012), Sustainable housing applications and policies for low-income self-build and housing rehab. Habitat International, 36, 312-323.

TALÒ, C., MANNARINI, T. and ROCHIRA, A. (2014), Sense of community and community participation: A meta-analytic review. Social Indicators Research, 117, 1-28.

TOWNSHEND, I., AWOSOGA, O., KULIG, J. and FAN, H. (2015), Social cohesion and resilience across communities that have experienced a disaster. Natural Hazards, 76, $913-$ 938.

WILKINSON, D. (2007), The multidimensional nature of social cohesion: Psychological sense of community, attraction, and neighboring. American Journal of Community Psychology, 40, 214-229. 